\title{
Denervation of the Motor Endplate Results in the Rapid Expression by Terminal Schwann Cells of the Growth-associated Protein GAP-43
}

\author{
C. J. Woolf, ${ }^{1}$ M. L. Reynolds, ${ }^{1}$ M. S. Chong, ${ }^{1}$ P. Emson, ${ }^{2}$ N. Irwin, ${ }^{3}$ and L. I. Benowitz ${ }^{3}$ \\ 'Department of Anatomy and Developmental Biology, University College London, London WC1E 6BT, England, ${ }^{2 M R C}$ \\ Group, Department of Neuroendocrinology, Institute of Animal Physiology and Genetics, Cambridge CB2 4AT, England, \\ and ${ }^{3}$ Department of Neurosurgery, Childrens Hospital, Harvard Medical School, Boston, Massachusetts 02115
}

Developing and regenerating neurons express high levels of the growth-associated phosphoprotein GAP-43. This membrane protein is not confined to neurons, however, as a number of studies have demonstrated GAP-43 immunoreactivity in central and peripheral glia in vitro and in vivo. We have found that the Schwann cells overlying the terminal motor axon at adult rat skeletal muscle endplates, and the motor axons themselves, are normally not GAP-43 immunoreactive. Within $24 \mathrm{hr}$ of denervation, however, the terminal Schwann cells are positive for a GAP-43 mRNA in situ hybridization signal and are GAP-43 immunoreactive. The immunoreactive GAP-43 cells possess elaborate processes that branch from the endplate region into the perisynaptic zone and stain with defined Schwann cell markers: the calcium binding protein $\mathrm{S100}$ and the low-affinity NGF receptor (NGFr), but not with a fibroblast marker, Thy-1. Reinnervating motor axons are GAP-43 positive, with an appearance quite different from the GAP-43-positive Schwann cells. The reappearance of nerve endings at the motor endplate is followed by the disappearance of GAP-43 labeling in the Schwann cells and of a retraction of their processes. GAP-43 expression in Schwann cells is therefore state dependent, apparently regulated by neural contact. This protein, which is associated in neurons with neurite formation, may participate in the elaboration of processes by Schwann cells when their contact with axons is disrupted.

The phosphoprotein GAP-43 (B-50, F-1, neuromodulin, pp-46; Benowitz and Routtenberg, 1987; Skene, 1989) is produced by developing neurons, where it accumulates in elongating axons and their growth cones (Meiri et al., 1986; Skene et al., 1986; Reynolds et al., 1991). Once target innervation is completed, the levels in most neurons fall, but it is reexpressed after axonal injury in those adult neurons whose axons regenerate (Skene and Willard 1981; Benowitz and Lewis, 1983; Hoffman, 1989; Tetzlaff et al., 1989; Van der Zee et al., 1989) and in those central neurons with the potential to regenerate (Doster et al., 1991). Although GAP-43 has been considered to be a neuron-

Received Nov. 25, 1991; revised Apr. 15, 1992; accepted May 22, 1992.

This work was supported by grants from the MRC and ISRT (C.J.W./P.E.), the Wellcome Trust (C.J.W.), a Bristol-Myers Unrestricted Pain Research grant (C.J.W.), NIH Grant EY 05690 (L.I.B./N.I.), and the Boston Neurosurgical Foundation (L.I.B./N.I.). We thank D. Blundell for technical assistance.

Correspondence should be addressed to Clifford J. Woolf, M.D., Ph.D., Department of Anatomy and Developmental Biology, University Collcge London, Gower Street, London WCIE 6BT, England..

Copyright (C) 1992 Society for Neuroscience $0270-6474 / 92 / 123999-12 \$ 05.00 / 0$ specific protein, it is now apparent that it is also detectable in some central and peripheral glia. GAP-43 immunoreactivity has been demonstrated in type 2 astrocytes, immature oligodendrocytes, and their precursors (Vitkovic et al., 1988; da Cunha and Vitkovic, 1990; Deloulme et al., 1990; Curtis et al., 1991). Schwann cells grown with sensory neurons in dorsal root ganglion cell cultures transiently express GAP-43 (Woolf et al., 1990), and pure Schwann cell cultures have been shown to synthesize GAP-43 (Curtis et al., 1992). Distal to a peripheral nerve crush lesion, GAP-43 immunoreactivity has been demonstrated in Schwann cells, and although its origin was originally thought to be axonal (Tetzlaff et al., 1989), it is now recognized that Schwann cells in degenerating peripheral nerves have the capacity to synthesize GAP-43 (Bisby et al., 1991; Curtis et al., 1992). A recent study has shown that while all developing Schwann cells express GAP-43 in the embryo, only non-myelinforming Schwann cells express the protein constitutively in normal adult nerves (Curtis et al., 1992). Adult myelin-forming Schwann cells are not normally immunoreactive for GAP-43 but become so several weeks following nerve degeneration (Curtis et al., 1992).

The presence of a protein in glial cells, which in neurons is associated with axonal growth, raises several questions. Under what circumstances is GAP-43 expressed in these cells, how does this relate to axon-glial contact, and what functional role may the molecules play in these non-neuronal cells? We have addressed the first two questions by examining GAP-43 immunoreactivity in the Schwann cells present on adult skeletal muscle motor endplates, and by using in situ hybridization to detect the presence of GAP-43-related mRNA. Terminal Schwann cells at the motor endplate are non-myelin-forming cells surrounding a single large terminal axon and its branches at a highly specialized synaptic zone. Within hours of denervation, axonal degeneration can be seen by electrophysiological and morphological techniques to have begun at the endplate (Miledi and Slater, 1970; Manolov, 1974; Gorio et al., 1983). This is accompanied by morphological changes in the terminal Schwann cells that include the formation of long processes that extend into the presynaptic zone, but that withdraw on reinnervation (Reynolds and Woolf, 1992). Denervation of muscle has previously been shown to result in the appearance of GAP43 immunoreactivity at the degenerating prejunctional apparatus, but its origin and cellular location were not characterized (Verhaagen et al., 1988). We have now shown that denervationinduced changes in terminal Schwann cell morphologyy are associated with the appearance and disappearance of GAP-43 immunoreactivity. 


\section{Materials and Methods}

Adult Sprague-Dawley rats (200-300 gm) were anesthetized with fentanyl and diazepam, and the sciatic nerve in the popliteal fossa was either cut with a ligation of the proximal stump or crushed for $20 \mathrm{sec}$ using a modified Spencer-Wells forceps with smooth grips, which produces a $2 \mathrm{~mm}$ area of translucency of the nerve. The wound was closed in two layers and the animals were allowed to recover.

At survival times of $18 \mathrm{hr}$ to $60 \mathrm{~d}$, pairs of animals from both procedures were terminally anesthetized with pentobarbitone $(50 \mathrm{mg} / \mathrm{kg}$, i.p.) and perfused with saline followed either with $4 \%$ paraformaldehyde in $0.1 \mathrm{M}$ phosphate buffer ( $\mathrm{pH} \mathrm{7.4)}$ ) or with a periodate-lysine-paraformaldehyde fixative (McLean and Nakane, 1974). The ipsi- and contralateral tibialis anterior and soleus muscles were then removed and pinned on a silicon rubber-coated petri dish filled with fixative. Following 6$8 \mathrm{hr}$ postfixation, the muscles were immersed in graded sucrose solution up to $20 \%$ in $0.1 \mathrm{M}$ phosphate buffer for cryoprotection.

Longitudinal sections $50-100 \mu \mathrm{m}$ thick were cut on a freezing microtome and collected in $0.1 \mathrm{M}$ phosphate-buffered saline (PBS), $\mathrm{pH}$ 7.4. The sections were incubated free-floating in $0.5 \% \mathrm{H}_{2} \mathrm{O}_{2}$ in PBS for $20-$ $30 \mathrm{~min}$ at $20-24^{\circ} \mathrm{C}$ to reduce endogenous peroxidase activity. Alternate sections were stained for cholinesterase by incubating in a solution of bromoindoxyl acetate, potassium ferricyanide, potassium ferrocyanide, and calcium chloride in Tris buffer at $37^{\circ} \mathrm{C}$ (Alderson et al., 1989). Both the cholinesterase-stained and unstained sections were then processed for immunocytochemistry. Sections were preincubated in a $10 \%$ solution of appropriate normal serum (20-30 $\mathrm{min})$, and then the following antisera were applied to adjacent sections: (1) polyclonal anti-GAP-43 $\left(1: 1000\right.$ to $1: 3000$ ) for $24 \mathrm{hr}$ at $4^{\circ} \mathrm{C}$ ) (Benowitz et al., 1988); (2) polyclonal anti-S100 (Dako) (1:800 to $1: 2400)$ for $12 \mathrm{hr}$ at $4^{\circ} \mathrm{C}$; (3) polyclonal protein gene product 9.5 (PGP 9.5) (Ultraclone) (Wilson et al., 1988) (1:1000 to $1: 1500$ ) for $12-24 \mathrm{hr}$ at $4^{\circ} \mathrm{C}$; (4) polyclonal anti-calcitonin gene-related peptide (CGRP), gift of M. Iadorola, NIH (Traub et al., 1989) (1:1500 to 1:30,000) for 24-36 hr at room temperature; (5) monoclonal anti-low affinity-NGF receptor (anti-NGFr) (192 IgG; Chandler et al., 1984), gift of E. Johnson, University of Washington (1:500), for $12 \mathrm{hr}$ at $4^{\circ} \mathrm{C}$; (6) polyclonal rabbit antiserum to a $\beta$-galactosidase/GAP43 fusion protein (Curtis et al., 1991), a gift of $\mathbf{R}$. Curtis, Regeneron, New York (diluted 1:5000 to 1:20,000), for $24 \mathrm{hr}$ at $4^{\circ} \mathrm{C}$. Dilutions were made in PBS containing 1\% appropriate normal serum and $0.4 \%$ Triton $\mathrm{X}-100$, plus $0.01 \%$ azide for incubations longer than $12 \mathrm{hr}$.

After washing with several changes of PBS for $1-2 \mathrm{hr}$, the following steps were carried out at room temperature with buffer washes after each step. Sections were incubated with the appropriate biotinylated IgG (Vector Laboratories) diluted 1:150 or 1:250 for 1-2 hr followed by Vectastain ABC reagent. The sections were then incubated in a $0.05 \%$ solution of 3,3'-diaminobenzidine tetrahydrochloride in Tris buffer + $0.01 \% \mathrm{H}_{2} \mathrm{O}_{2}$ for $10 \mathrm{~min}$. Following several washes with water, the sections were mounted on gelatinized slides, dehydrated, and coverslipped with DPX mountant. Substitution of primary antisera and of biotinylated IgGs by either nonimmune serum or PBS was performed for all the sets of tissue, and in each case these controls were negative.

Preabsorption of the GAP-43 antibody with 100-fold purified rat brain GAP-43 from postnatal day 4 rat cortex, extracted with Triton $\mathrm{X}-100$ and separated by DEAE chromatography $(0.2 \mathrm{M} \mathrm{NaCl}$ elution, $\mathrm{pH} 7.5$ ), was performed by mixing aliquots of the antibody with increasing strengths of the GAP-43 protein. These were incubated at $37^{\circ} \mathrm{C}$ for $1 \mathrm{hr}$, stored overnight at $4^{\circ} \mathrm{C}$, and centrifuged. Controls were similarly treated with BSA.

Western blotting. Proximal and distal nerve scgments ipsilateral to a sciatic nerve cut or crush performed $1,4,10$, or $30 \mathrm{~d}$ earlier, together with the intact contralateral sciatic nerve, were collected from terminally anesthetized rats, weighed, and freeze dried. The sciatic nerve segments were then homogenized in SDS-sample buffer $(10 \mathrm{mg}$ wet $\mathrm{wt} / \mathrm{ml}$ of buffer containing $1 \%$ SDS, $0.125 \mathrm{~m}$ Tris- $\mathrm{HCl}, \mathrm{pH} 6.8,5 \% \beta$-mercaptoethanol, $10 \%$ glycerol), heated at $95^{\circ} \mathrm{C}$ for $5 \mathrm{~min}$, and loaded into the wells of two SDS gels, one for protein staining and the other for transfer to nitrocellulose (stacking gel, $4.5 \%$ acrylamine, $3 \mathrm{~cm}$ height; resolving gel $10 \mathrm{~cm}$ in height; Laemmli, 1970). Gels were run overnight until the dye front was $\sim 1 \mathrm{~cm}$ from the bottom. One gel was stained with Coomassie brilliant blue (Bio-Rad); the other was equilibrated for $1 \mathrm{hr}$ in transfer buffer (Towbin et al., 1979) and then transferred electrophoretically to nitrocellulose membrane $(0.6 \mathrm{~A}, 3.5 \mathrm{hr}$ with cooling). Filters were blocked in $50 \mathrm{~mm}$ Tris-buffered saline (TBS, pH 7.5) containing $5 \% \mathrm{BSA}$ and $5 \%$ normal rabbit serum ( $1 \mathrm{hr}$, room temperature), reacted overnight in primary antibody (affinity-purified sheep anti-GAP-43 IgG fraction, 1:1000 in $50 \mathrm{~mm}$ Tris containing $0.2 \%$ Tween-20, $300 \mathrm{~mm}$ $\mathrm{NaCl}, 5 \%$ rabbit serum, $5 \% \mathrm{BSA}$ ), washed three times in TBS with Tween-20 and elevated salt (once for at least $3 \mathrm{hr}$ ), reacted with the secondary antibody [rabbit anti-sheep IgG conjugated to horseradish peroxidase (HRP; Vector Labs) in the same buffer used for the primary antibody], washed twice with TBS and once with $50 \mathrm{~mm}$ Tris buffer alone, and then reacted with diaminobenzidine $\mathrm{HCl}$ (Sigma, $10 \mathrm{mg} / 20$ $\mathrm{ml}$, in solution containing $0.1 \% \mathrm{H}_{2} \mathrm{O}_{2}$ and $0.25 \% \mathrm{NiCl}_{2}$ ).

In situ hybridization. This was performed on unfixed tissue removed under terminal anesthesia and frozen in liquid nitrogen. Tissue sections (soleus muscle, sciatic nerve, ipsi- and contralateral to a sciatic nerve cut or crush 1,3 , and 7 d previously) were cut on a cryostat $(20 \mu \mathrm{m})$, mounted on chrome-alum gelatinized slides, and air dried. Hybridization was performed using an alkaline phosphatase-linked GAP-43 CDNA probe (Kiyama et al., 1990; Wiese and Emson, 1991) as follows. The sections were washed in PBS acetylated for $10 \mathrm{~min}$ in a solution containing acetic anhydride, sodium chloride, and triethanolamine. The sections were then dehydrated through a series of increasing alcohol concentrations and delipidated in chloroform. After partial rehydration, hybridization was performed in $50 \%$ deionized formamide, Denhardt's solution, standard saline citrate buffer (SSC), $4 \%$ single-stranded salmon sperm DNA, and $10 \%$ dextran sulfate together with an alkaline phosphatase-labeled antisense oligonucleotide $(2-4 \mathrm{fmol} / \mu \mathrm{l})$ corresponding to nucleotide positions $119-157$ of the rat GAP-43 cDNA sequence (Basi et al., 1987). After hybridization at $24-48 \mathrm{hr}$ at $37^{\circ} \mathrm{C}$, the sections were washed in three changes of SSC buffer $(0.15 \mathrm{M} \mathrm{NaCl}, 0.015 \mathrm{M} \mathrm{Na}$ citrate, $\mathrm{pH} 7.0$ ) at $55^{\circ} \mathrm{C}$ followed by a wash at room temperature. The alkaline phosphatase was visualized by generating a color reaction in nitroblue tetrazolium chloride and 5-bromo-4-chloro-3-inodyl phosphate in Tris buffer $/ \mathrm{MgCl}_{2}$ as previously described (Wiese and Emson, 1991). Specificity of staining was tested by pretreating the tissue with Ribonuclease $\Lambda$ (Sigma; $0.5 \mathrm{mg} / \mathrm{ml}$ ) to digest cellular mRNA or by competition with an excess $(100 \times)$ of unlabeled oligonucleotide added to the hybridization solution. The tissue for each preparation was incubated in the presence or absence of the enzyme-linked probe and the sections evaluated blind. In two experiments, adjacent sections were stained for the GAP-43 mRNA and for motor endplates using cholinesterase, as described above.

Guanethidine sympathectomy. In order to differentiate postganglionic sympathetic terminals from motor axons or Schwann cells at the endplate, immunohistochemistry for GAP-43 was performed in animals pretreated postnatally with guanethidine to eliminate their sympathetic nervous system $(50 \mathrm{mg} / \mathrm{kg}$ guanethidine sulfate subcutaneously from day 8 after birth to 3 weeks, 5 d per week; Aberdeen et al., 1990). The efficacy of the treatment was established by measuring the depletion of noradrenaline levels (Aberdeen et al., 1990).

Northern blot analysis. Following terminal anesthesia, the sciatic nerve distal and proximal to a cut and ligation was removed together with the contralateral intact sciatic nerve and the ipsi- and contralateral L3, -4 , and -5 dorsal root ganglia. Tissues from four animals were pooled together 2 and $4 \mathrm{~d}$ postsciatic section after having been frozen on dry ice. Total RNA was extracted by homogenization in $4 \mathrm{~m}$ guanidium thiocyanate buffer (Chirgwin et al., 1979). Total RNA (10 $\mu \mathrm{g} /$ sample) was separated on formaldehyde-agarose gels, transferred to nitrocellulose membranes, and hybridized with GA11B, a 1.1 kilobase cDNA to GAP-43 (Neve et al., 1987). The cDNA was labeled with ${ }^{32} \mathrm{P}-\mathrm{CTP}$ using the random priming method. Washed blots were exposed to Kodak X-Omat AR film (1-33 d).

\section{Results}

\section{GAP-43 immunohistochemistry}

The motor endplates of the intact soleus and tibialis anterior muscles showed no GAP-43 immunoreactivity (Figs. $1 a, a^{*} ; 2 a$ ). The only GAP-43-labeled structures in the intact muscle were sympathetic axons innervating blood vessels throughout the muscle, which were not present in the rats sympathectomized at birth by guanethidine treatment. Denervation of the muscles by either a cut or crush lesion of the sciatic nerve resulted in the appearance of GAP-43 immunoreactivity at the motor endplates by $18 \mathrm{hr}$. This consisted of cellular profiles with a distribution and appearance identical to that of terminal Schwann cells labeled with S-100 in immediately adjacent sections. The 
GAP-43-labeled profiles were confined to the motor endplate at this stage, defined by cholinesterase staining of the endplate basement membrane (Figs. 1a, 2a). A previous study in our laboratory has demonstrated that $3 \mathrm{~d}$ following denervation, terminal Schwann cells form elaborate processes that branch into the perijunctional space (Reynolds and Woolf, 1992). We have now found that at this time postdenervation, both the terminal Schwann cells at the endplate and their processes are GAP-43 immunoreactive (Figs. $1 b, b^{*} ; 2 b^{*} ; 3 A$ ). These GAP43-positive ccllular profiles and processes are identical to S-100and NGFr-positive Schwann cell structures seen on adjacent sections (Fig. 4), which have been described in detail in the earlier study (Reynolds and Woolf, 1992). Schwann cells in intramuscular nerves and in terminal branches also became GAP-43 immunoreactive and, like the Schwann cells at the endplate, were characterized by intense staining of the membrane cytoplasm, but not of the nucleus (Fig. $3 A$ ).

Similar patterns of GAP-43 immunoreactivity were seen at 1 week following either nerve cut or crush, both showing more extensive perijunctional processes than at $3 \mathrm{~d}$ (Fig. $2 c, c^{*}$ ). As at the earlier time, the appearance, location, and distribution of the GAP-43-labeled cellular profiles and processes were indistinguishable from those labeled by the Schwann cell markers S-100 and NGFr (Fig. 4). The GAP-43 immunoreactivity was quite different in appearance from perineural and other fibroblasts in the dencrvated junctional and perijunctional area, visualized with anti-Thy-1 (Reynolds and Woolf, 1992). By $16 \mathrm{~d}$, differences could be detected between the crush and cut preparations. In the former, fine single GAP-43-labeled processes directed to the endplate and forming a branching pattern characteristic of terminal motor axons were present (Figs. 1c, $c^{*}$; $3 C, D)$. At those individual endplates where such axon-like GAP43-positive structures were present, immunolabeled Schwann cell-like cellular profiles were not seen. In adjacent sections, axons labeled with CGRP or PGP 9.5 innervated equivalent numbers of endplates in a distribution and pattern identical to the axon-like GAP-43 label (Fig. 4). No endplate CGRP or PGP 9.5 label was present at 3 and $7 \mathrm{~d}$ post-crush or at $16 \mathrm{~d}$ postcut when Schwann cell-like GAP-43 immunoreactivity was present. Figure $3 C$ is a camera lucida reconstruction of axonlike GAP-43 profiles and shows that in some cases they possessed a growth conc-likc appearance.

Three features distinguishing the GAP-43-immunoreactive Schwann cell label at the endplate from the axonal-like GAP-
43 label were the much finer diameter of the stained terminal branches for the axons than the Schwann cells (compare Fig. $3 A, D)$; the absence of any cell body profiles in the axon-like stains, which was always a feature of the Schwann cell markers; and finally, the terminal branching pattern at the endplate. This had a delicate lace-like pattern for the axonal stain, with fine individual processes branching from the terminal axon across the endplate in a manner identical to that found with CGRP and PGP 9.5 (Fig. 4), while the Schwann cell staining pattern was coarser so that individual elements of the terminal network at the endplate could not be distinguished readily from each other, as was also true for the S-100 or NGFr staining patterns (Fig. 4). The intensity of GAP-43 immunoreactivity in the Schwann cells and axons was very comparable and was detected at similar titers of the antibody.

In those preparations where the sciatic nerve had been sectioned and ligated $16 \mathrm{~d}$ earlier, the GAP-43 label persisted in a disorganized, branching pattern (Figs. $2 d, d^{*} ; 3 B$ ) with extensive processes and cellular elements both at the endplate and in the perijunctional zone.

Thirty days following a crush lesion, all GAP-43 immunoreactivity at the endplates had an axonal appearance (Fig. $1 d, d^{*}$ ). At this time, the terminal Schwann cells have returned to their normal S-100 staining pattern and NGFr label has almost disappeared (Reynolds and Woolf, 1992). Effectively, all the GAP-43 immunoreactivity at the endplate had disappeared $60 \mathrm{~d}$ postcrush (Fig. 1e,e*). Following sciatic section, GAP-43 immunoreactivity remained at the endplate region at 30 and $60 \mathrm{~d}$, with intense labeling of intramuscular nerves and a very disorganized staining pattern in the junctional zone (Fig. 2e, $e^{*}$ ), which closely resembled $\mathrm{S}-100$ staining. That the endplate GAP43 label was not of sympathetic axon origin was shown by identical staining patterns produced by denervation in sympathectomized (neonatal guanethidine) and nonsympathectomized rats.

The terminal Schwann cell staining pattern at denervated endplates, obtained with a sheep polyclonal antibody raised against purified rat GAP-43 (Benowitz et al., 1988), was also found with an antibody raised in rabbits to a $\beta$-galactosidase/ GAP-43 fusion protein (Curtis et al., 1991, 1992), but at much lower titers, $1 / 15,000$ versus $1 / 2000$.

Preabsorption of the Benowitz anti-GAP-43 antibody with GAP-43 protein extracted from $4 \mathrm{~d}$ rat cortex resulted in a concentration-dependent reduction in staining and the intensity

Figure 1. Photomicrographs of longitudinal sections through the junctional zone of the soleus muscle, immunostained for GAP-43. The sections in the columns on the left are only stained for GAP-43; those on the right $\left(^{*}\right)$ are also stained for AChE. $a$ and $a^{*}$ show sections through a normally innervated control muscle. Note the absence of GAP-43 label at the junctional zone $(a)$ and the distribution of the endplates revealed by AChE staining of the basement membrane (arrow, $a^{*}$ ). $b$ and $b^{*}$ show the appearance of GAP-43 immunoreactivity $3 \mathrm{~d}$ following a crush lesion to the sciatic nerve. Short fat arrows, GAP-43-positive intramuscular nerves; long thin arrows, cellular profiles at the endplate; small arrows, GAP-43positive extrajunctional fine processes. $c$ and $c^{*}$ show that $16 \mathrm{~d}$ post-crush a mixture of axonal label (long thin arrow) and Schwann cell processes (small arrows) are present. By $30 \mathrm{~d}\left(d\right.$ and $\left.d^{*}\right)$, only axonal profiles are GAP-43 positive, terminating in characteristic structures at the endplate (arrow). Sixty days post-crush ( $e$ and $e^{*}$ ), the only GAP-43-positive structures in the muscle are sympathetic axons innervating blood vessels (arrow). Scale bars, $50 \mu \mathrm{m}$.

Figure 2. The effect of sciatic nerve section on GAP-43 immunoreactivity at the soleus muscle inotor endplate. Plate a shows the absence of any GAP-43-positive structures at endplates, labeled with AChE (arrow), in a control muscle. Three days post-sciatic nerve section, GAP-43-labeled processes emerge from endplates (arrow, $b^{*}$ ). This pattern and that found after $7 \mathrm{~d}\left(c\right.$ and $\left.c^{*}\right)$ are effectively indistinguishable from that found after sciatic nerve crush (Fig. 1). $c$, A low-power photomicrograph illustrating the limit of staining to the general vicinity of the junctional zone, except for sympathetic axons (arrow). However, the Schwann cell-like label at the endplate (long thin arrow; see Fig. 4) possesses elaborate extrajunctional branches (short arrow; $c^{*}$ ). Sixteen days post-section, at a time when axonal label can be seen in crush nerve preparations (Figs. 1, 4), the GAP43 label at the denervated endplate is still Schwann cell-like with even more extensive branches emerging from cellular profiles (short arrows, $d$ ) at the endplate (long arrow, $\left.d^{*}\right)$. Staining persists at $60 \mathrm{~d}$ post-section ( $e$ and $e^{*}$ ) with heavy label of intramuscular nerves (thick arrows) and a disorganized pattern of label at the general endplate region (long thin arrow). All sections stained for AChE are labeled with *. Scale bars, $50 \mu \mathrm{m}$. 
a
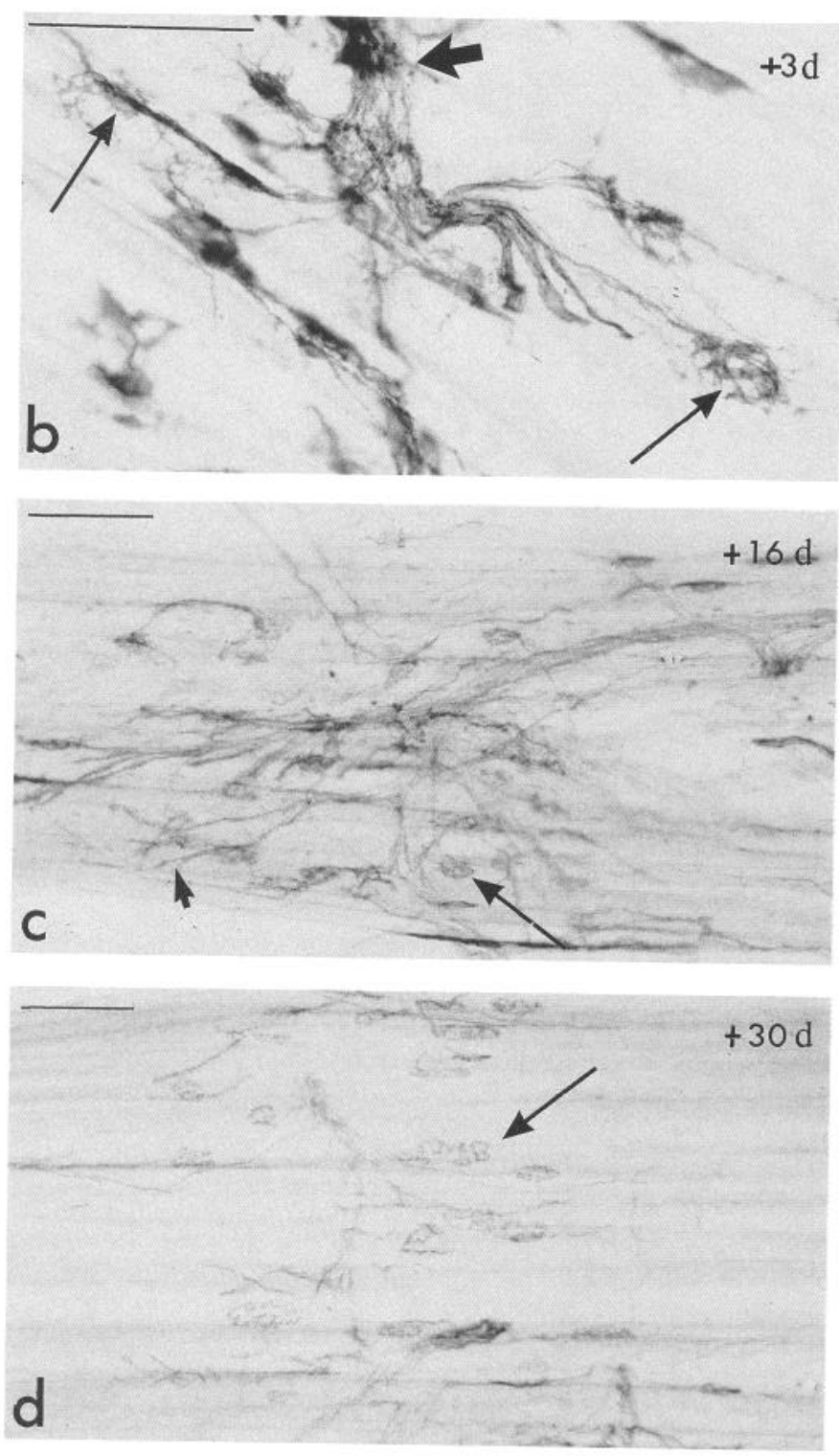

$+60 d$

e

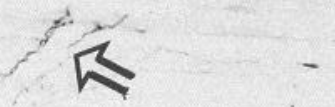

.
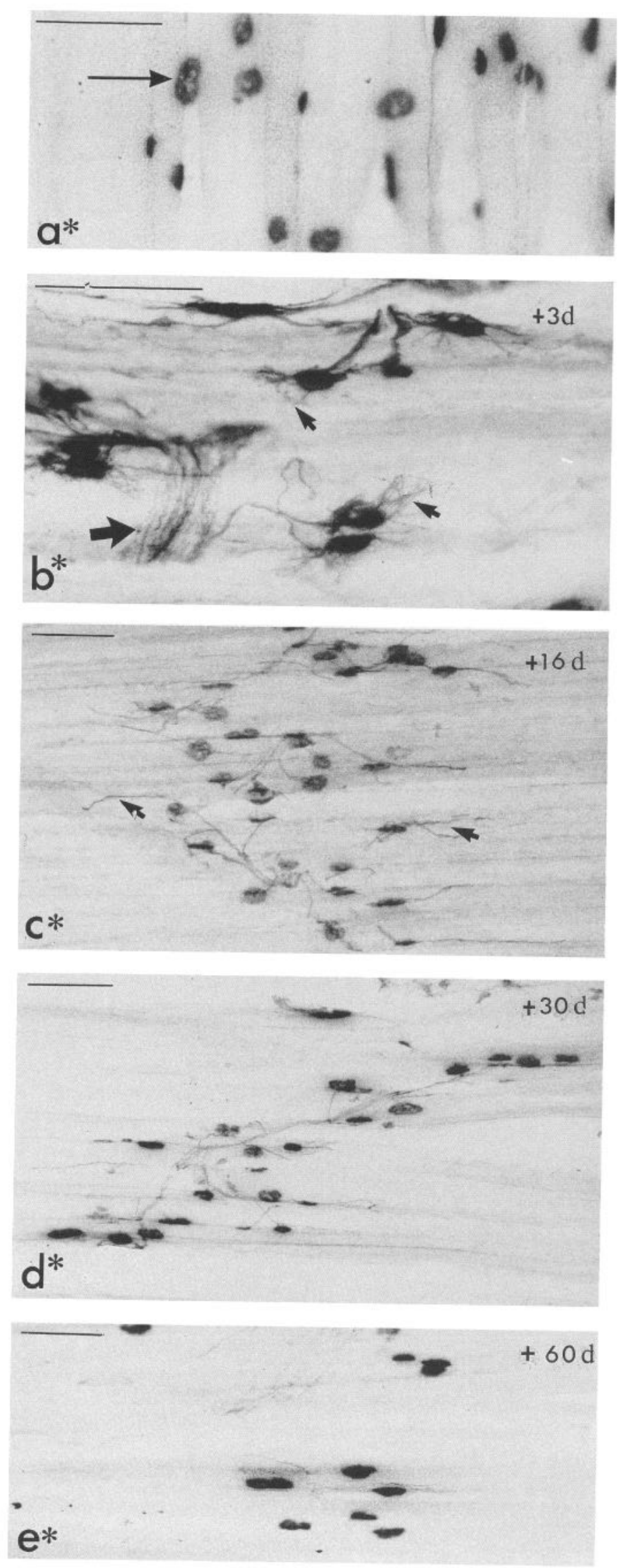

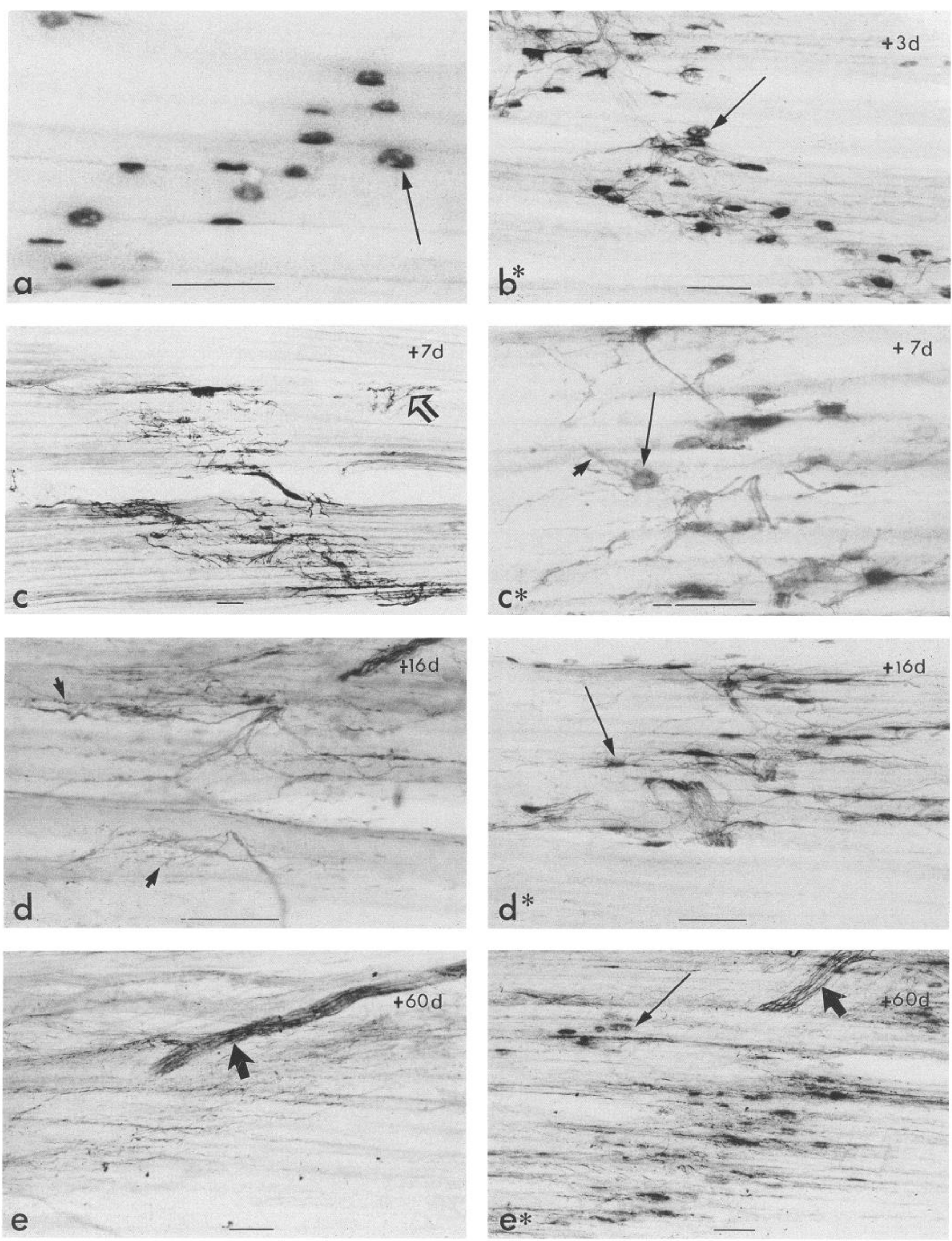


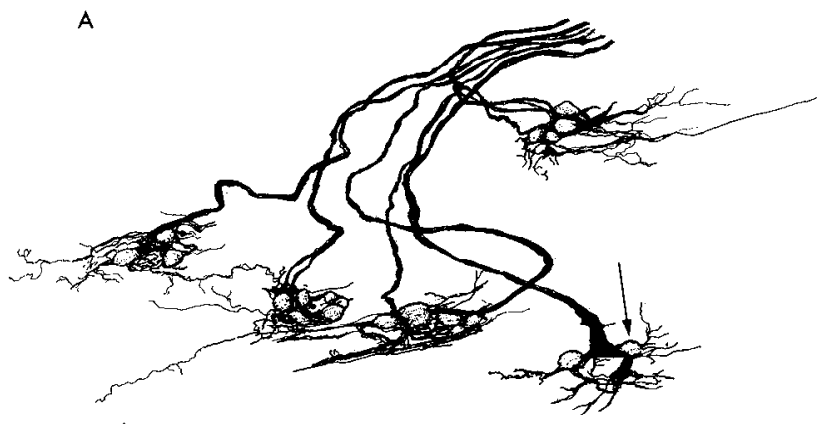

3d CUT
B
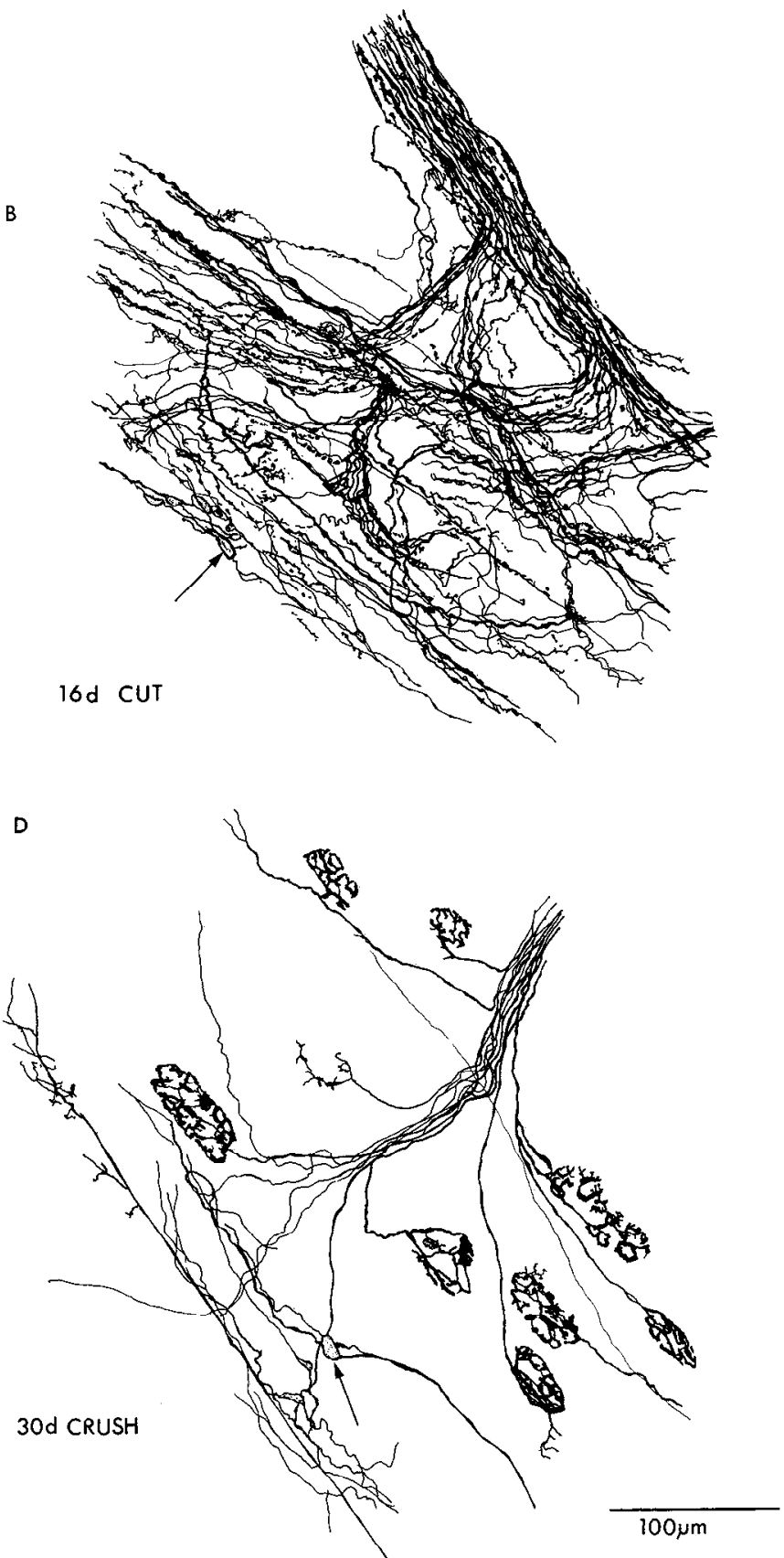

Figure 3. Camera lucida reconstructions of GAP-43-labeled profiles at the endplate region of the soleus muscle at various times after sciatic nerve cut or crush. In $A$, the arrow indicates GAP-43-positive cellular profiles at the endplate $3 \mathrm{~d}$ after a cut. $B$ illustrates the more extensive and disorganized label found at $16 \mathrm{~d}$ after a sciatic nerve section with a cellular profile (arrow). At $16 \mathrm{~d}$ following a crush lesion, an axonal-like stain is present with fine terminal branches ending in the characteristic end terminal spray. In some cases, as illustrated in $C$, the axon terminals appear flattened with filopodia, similar to growth cones. At $30 \mathrm{~d}$ post-crush, the GAP-43 axonal-like stain is identical to that found with other axonal stains, and the characteristic endplate terminal axonal spray is readily seen although a few labeled cellular profiles (arrow) remain.

of the denervated endplate. Beyond certain concentrations, the staining was abolished. Antibody incubated with BSA showed no reduction in staining.

\section{GAP-43-Western blots}

As presented in Figure $5 A$, the anti-GAP-43 antibody used in these studies showed little staining of proteins present in the normal sciatic nerve, but stained a band migrating at $\sim 48 \mathrm{kDa}$ in sciatic nerves undergoing regeneration $10 \mathrm{~d}$ after injury. An elevation in GAP-43 levels in regenerating axons at this time point is expected from other studies (Skene and Willard, 1981; Tetzlaff et al., 1989; Van Hoof et al., 1988). Figure $5 B$ demonstrates that GAP-43 is present not only in regenerating axons, but also in peripheral nerve segments distal to a ligation that contain no axons. Four individual cases are shown here, two of which sustained a ligation and two a crush injury that allowed the nerves to regenerate. At $30 \mathrm{~d}$ after surgery, segments distal to the cut site (containing Schwann cells without axons) showed levels of GAP-43 that were similar to or higher than the proximal nerve segments (containing regenerating axons) and con- 

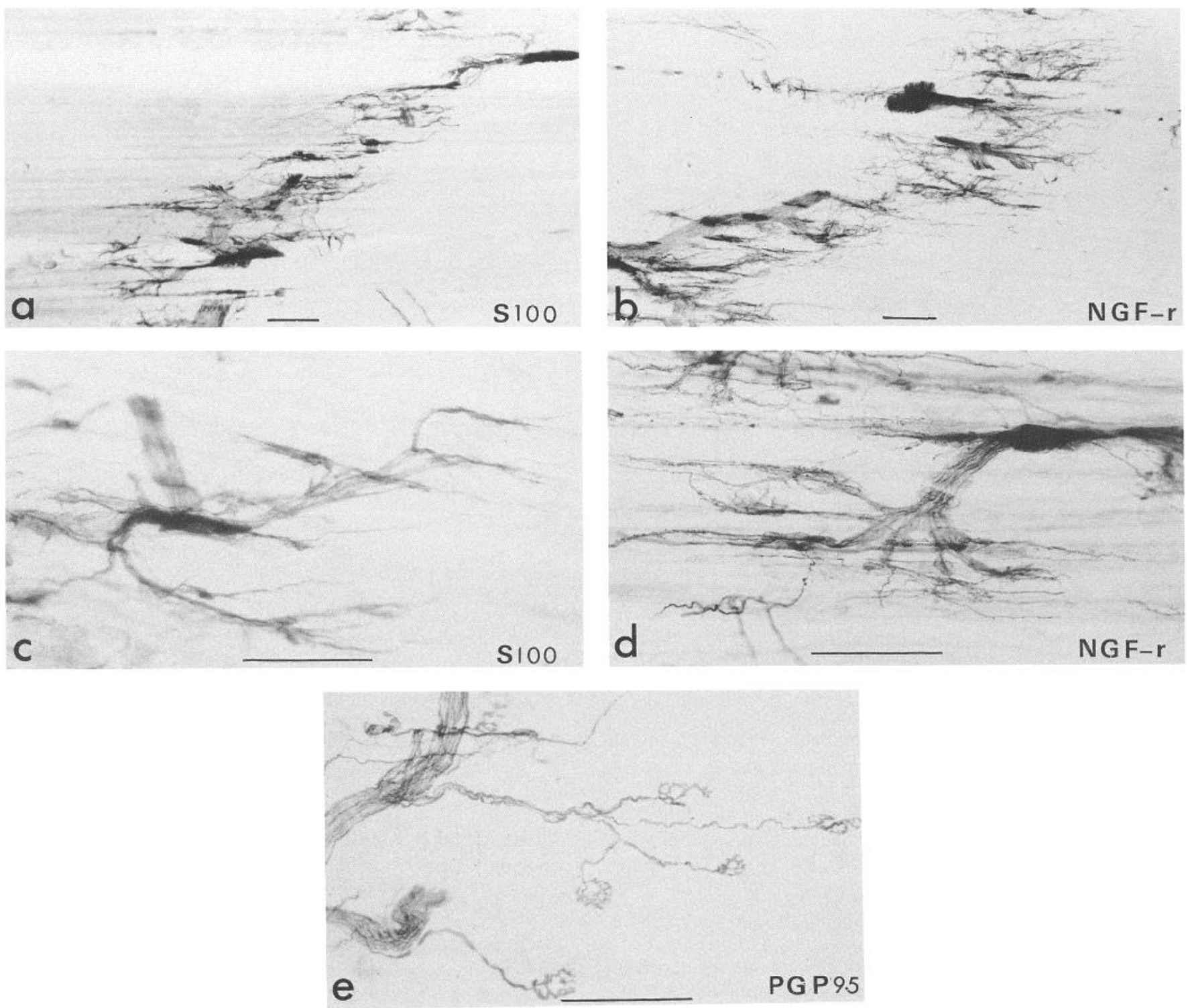

Figure 4. Photomicrographs illustrating the appearance of the Schwann cell markers $\mathrm{S}-100(a, c)$ and NGFr $(b, d)$ at a $7 \mathrm{~d}$ denervated soleus muscle, and an axonal marker PGP $9.5(e)$ at a reinnervated muscle ( $30 \mathrm{~d}$ post-crush). Plates $a$ and $b$ are low-power photomicrographs, and $c$ and $d$, high-power photomicrographs showing that the pattern of immunoreactivity produced by antibodies to NGFr and S-100 is indistinguishable from that found with GAP-43 (see Figs. $\left.1 b, b^{*} ; 2 c, c^{*}\right)$. Similarly, the labeling produced by the axonal marker PGP 9.5 is identical to the GAP-43 label found $30 \mathrm{~d}$ following a crush lesion (see Fig. 1d). Scale bars, $50 \mu \mathrm{m}$.

siderably higher than the contralateral (control) sides. In the two cases that sustained nerve crushes (cases 3 and 4), segments both proximal and distal to the site of injury showed only relatively modest levels of GAP-43 at $30 \mathrm{~d}$ consistent with the fact that nerve regeneration would be largely completed under these conditions. The relative amount of GAP-43 protein present in nerve segments $30 \mathrm{~d}$ after sciatic nerve cut (Fig. $5 B$ ) was considerably less than in a nerve segment distal to a crush injury $10 \mathrm{~d}$ earlier (Fig. 5A).

\section{GAP-43-in situ hybridization signal}

Cells staining positively for GAP-43 related mRNA were not found either in intact muscle or peripheral nerve $(n=7)$. One day following sciatic cut or crush, labeled cellular profiles could be detected in the junctional zone of the soleus muscle $(n=4)$. Not all endplates were labeled, and little label was found in intramuscular nerves and none in the sciatic nerve. No stained cells were found outside the junctional zone. A similar picture was present 1 week after sciatic nerve cut $(n=2)$ or crush $(n=$ 1) although more endplates were labeled (Fig. 6A). At each endplate, a group of labeled cells was found (Fig. $6 B$ ). When adjacent sections were stained for cholinesterase and for GAP43-related mRNA, the distribution of the mRNA was found to match the endplates very closely (Fig. $6 \mathrm{C}$ ). Two weeks postsection, the intensity of the signal had declined considerably $(n=$ 1). A positive control for the technique was the detection of GAP-43-related mRNA in axotomized motor neurons in the lumbar spinal cord. Within a day of section, motor neurons ipsilateral to the sciatic cut or crush became positive for GAP43-related mRNA, the staining intensity reached a peak at 2 weeks with all axotomized neurons containing the mRNA.

No staining was found in the muscles in the absence of the 
A

B
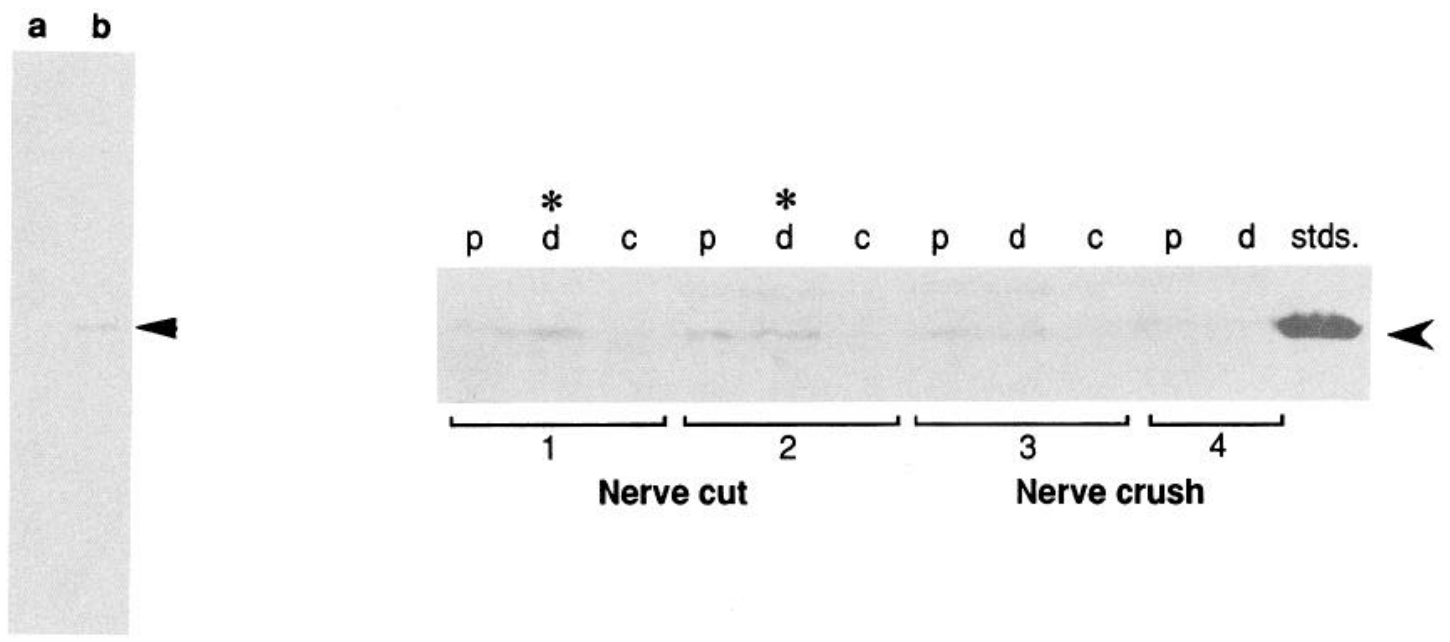

Figure 5. Western blots of sciatic nerve proteins. Proteins were separated on $10 \%$ SDS-polyacrylamide gels (100 $\mu \mathrm{g}$ per lane), transferred to nitrocellulose membranes, and probed with an affinity-purified antibody to GAP-43 (at 1:1000 dilution; Benowitz et al., 1988). A, Specificity of the anti-GAP-43 antibody. $a$, No signal is detected in the normal sciatic nerve; $b$, in nerves crushed at the mid-thigh level $10 \mathrm{~d}$ previously, a single band migrating with an apparent molecular size of $48 \mathrm{kDa}$ is detected (arrowhead). B, GAP-43 levels increase in peripheral nerve segments that do not contain axons $30 \mathrm{~d}$ after ligation. The blot shows segments proximal to the site of nerve injury $(p)$, distal to the site of injury $(d)$, or in the contralateral nerve $(c)$. Numbers below gel lanes refer to individual cases, two of which sustained a unilateral nerve transection (cut, 1,2$)$ and the other two a crush injury at mid-thigh level that allowed the nerve to regenerate (crush, 3,4). In cases 1 and 2 , GAP-43 is detected in nerve segments both proximal and distal $(*)$ to the injury. In cases 3 and 4 , where axons can regenerate through the distal nerve segment, levels of GAP-43 detected $30 \mathrm{~d}$ after surgery were generally lower in both segments. In all cases, levels of GAP-43 in intact nerves (contralateral to surgery) were low. The GAP-43 standard (stds.; arrowhead) was partially purified from postnatal day 4 rat cortex by extraction with Triton X-100 and DEAE chromatography $(0.2 \mathrm{M} \mathrm{NaCl}$ elution, $\mathrm{pH} 7.5)$. The blots in $B$ were incubated in diaminobenzidine for considerably longer than the blots in $A$.

labeled oligonucleotide probe, and the staining produced by the labeled probe was eliminated either by pretreatment with RNase A or by incubation in the presence of an excess of unlabeled probe.

\section{GAP-43 mRNA-Northern blots}

No GAP-43 mRNA could be detected using this approach in intact sciatic nerves (two experiments, material pooled from four animals per experiment), the sciatic nerve proximal to a section at 2 and $4 \mathrm{~d}(n=2)$, or in the distal segment of the nerve at these times. Low levels of message were present in control dorsal root ganglia, and this increased approximately sixfold 4 d after sciatic section. GAP-43 mRNA could not be detected in normal or denervated ( $2 \mathrm{~d})$ muscle.

\section{Discussion}

GAP-43 has proved to be a useful marker of axonal growth in developing and regenerating neurons. This $24 \mathrm{kDa}$ acidic protein is bound to the inner surface of the axonal membrane (Skene and Virag, 1989) where it is a substrate for protein kinase C (Van Hoof et al., 1988), associated with G-protein activation (Strittmatter et al., 1990), binds to calmodulin (Alexander et al., 1987; Skene, 1990), and may modulate phosphoinositol phosphate turnover (Van Hoof et al., 1988). Blocking the expression or action of the protein with antisense oligonocleotides or with antibodies interferes with neurite outgrowth (Fidel et al., 1990; Schotman et al., 1990; Shea et al., 1991). The transfection of non-neuronal cells with GAP-43 cDNA results in process formation (Zuber et al., 1989; Yankner et al., 1990). This raises the possibility that this protein may have a role in neurite formation and growth in neurons, although the ability of certain PC12 cell lines deficient in GAP-43 to form processes in response to NGF (Baetge and Hammang, 1991) implies that this protein may not be an absolute requirement for neurite outgrowth. Our present observations point to a strong parallel between GAP-43 expression in denervated Schwann cells at the motor endplate and their formation of elaborate long fine branches. Within hours of denervation, GAP-43 immunoreactivity appears at motor endplates (see also Verhaagen et al., 1988). Reinnervation results in the loss of this Schwann cell GAP-43 immunoreactivity and the disappearance of the extensive Schwann cell processes. The GAP-43-containing cells at the denervated endplates shared the exact location and appearance of cells stained in adjacent sections with the glial cell markers S-100 (Brockes et al., 1977; Neuberger and Cornbrooks, 1989; Mata et al., 1990) and NGFr (Taniuchi et al., 1986, 1988).

Removing axon-Schwann cell contact in adult peripheral nerves results in a dedifferentiation of the myelin-forming Schwann cells. This manifests by the increased expression of markers such as NCAM (Jessen et al., 1985), the low-affinity NGF receptor (Taniuchi et al., 1986, 1988; Heumann et al., 1987; Jessen et al., 1990), and glial fibrillary acidic protein (Jessen et al., 1990) and by the reduction of markers such as myelin basic protein (Mirsky et al., 1980) or surface galactocerebrosides (Jessen et al., 1985). The development of GAP-43 immunoreactivity in denervated Schwann cells at the endplate and in intramuscular nerves may represent a similar dedifferentiation as all Schwann cell precursors express GAP-43 (Curtis et al., 1992) and denervation results in a reexpression that lasts only while the axon is absent. This indicates that GAP-43 expression in Schwann cells is state- or differentiation-dependent, and in this respect it resembles neuronal expression of the protein. The 

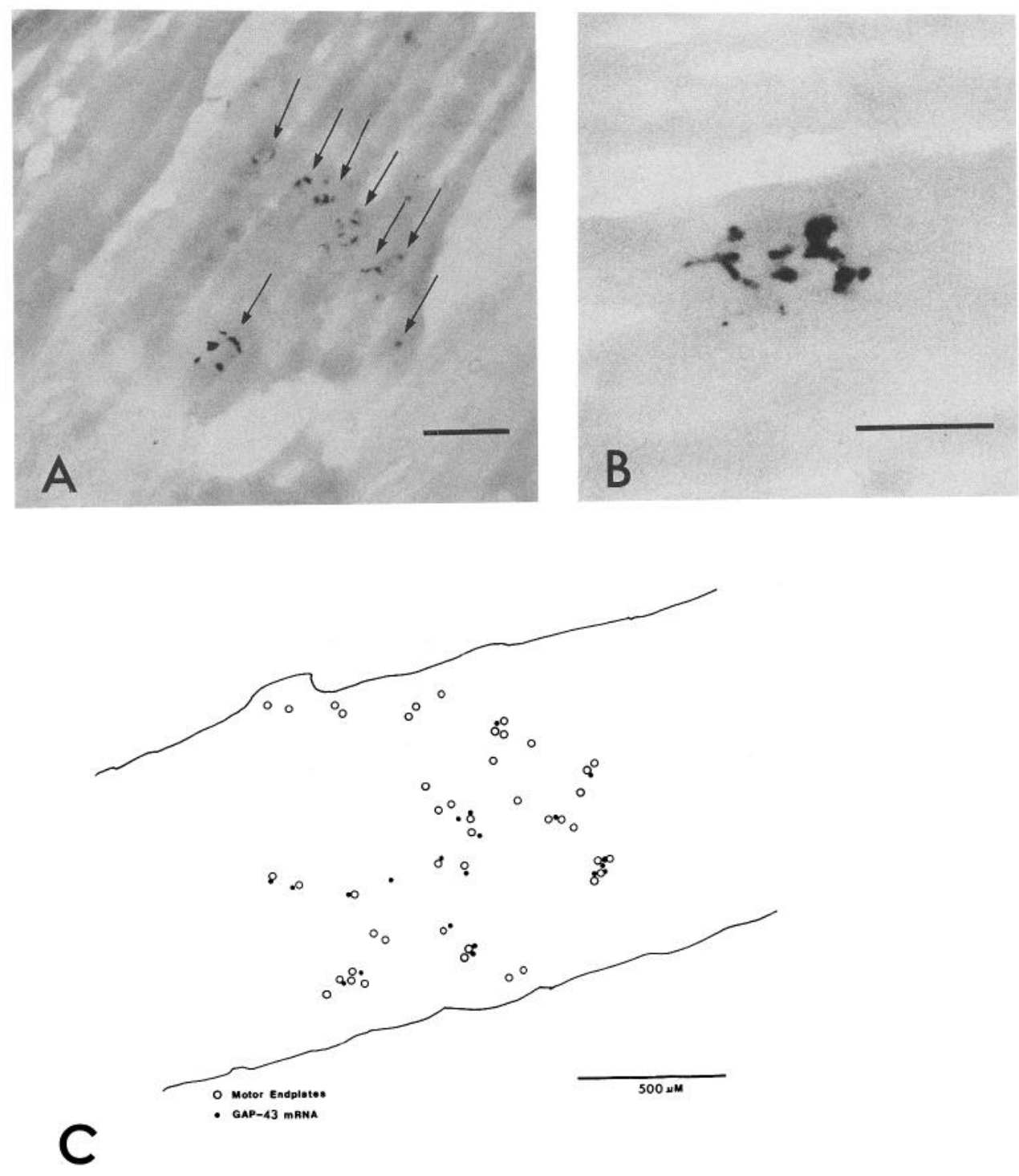

Figure 6. In situ hybridization label of GAP-43 mRNA at a $7 \mathrm{~d}$ denervated soleus muscle. $A$ is a low-power and $B$ a high-power photomicrograph illustrating the distribution of cells containing GAP-43 mRNA. Each arrow in $A$ indicates a collection of cells on a single muscle fiber at presumed endplates. $C$ is a map drawn with camera lucida microscope attachment showing the relative locations of endplates, defined by AChE staining in one section, and of cells containing GAP-43 mRNA in an immediately adjacent section. Scale bars: $A, 100 \mu \mathrm{m} ; B, 50 \mu \mathrm{m}$.

rapid expression of GAP-43 in Schwann cells in muscle nerves and at the endplate appears to be different from myelin-forming Schwann cells in the main peripheral nerve trunks, where expression has only been detected either at locations where regrowing axons have reached (Tetzlaff et al., 1989), or in distal stumps after a 4 week delay (Curtis et al., 1992). Whether this reflects a slowly progressing distal-proximal change in the Schwann cells, earlier access to signals that upregulate the GAP43 in muscle compared to nerve trunks, or a real difference in the Schwann cells in muscle and in nerves in terms of their response to removal of contact with axons is not known. The changes in GAP-43 expression we have found were not restricted to terminal Schwann cells, which are specialized and nonmyelin-forming, but were also observed in the intramuscular nerve branches where the Schwann cells surrounding motor axons are myelin forming.

Overall, the number of cells in the muscle that begin to express GAP-43 after denervation is very small, which must account for the failure to find GAP-43 mRNA by Northern blot analysis at times that a GAP-43 mRNA signal could be demonstrated by in situ hybridization. We, like others (Basi et al., 1987), also failed to detect any GAP-43 mRNA in distal nerve segments at short times following nerve section, which is not too surprising, since GAP-43 protein can only be detected in these Schwann cells after several weeks (Curtis et al., 1992). PCR amplification has demonstrated higher levels of GAP-43 mRNA in degenerating nerve samples than in intact nerves (Bisby et al., 1991), indicating once again that Schwann cells can express GAP-43. The amount of GAP-43 protein present in the Schwann cells and in regenerating motor neuron terminals at day 30 were relatively similar, in terms of the antibody titer required to visualize it, but the amount of GAP-43 protein in muscle samples was too low to be detected by Western blot analyses of whole muscle. Nevertheless, Western blots indicated that the antibody used in these studies recognized a single band at the appropriate molecular weight for GAP-43 in distal nerve segments containing no axons.

It is unlikely that the antibody was cross-reacting with other proteins that share specific sequences with GAP-43, particularly neurogranin (RC3), a phosphoprotein present in postsynaptic elements and that has an 18 amino acid calmodulin binding site that is almost identical to that present in GAP-43 (Watson et al., 1990; Baudier et al., 1991). Neurogranin and GAP-43 migrate quite differently on SDS gels (Baudier et al., 1991), and 
we found no evidence of a labeled band at 15-19 kDa, where neurogranin would be expected to be. In addition, the developmental regulation and cellular location of neurogranin and GAP-43 are completely different (Represa et al., 1990; Watson et al., 1990), and previously little cross-reactivityy of antibodies against the two proteins has been found (Represa et al., 1990). Preabsorption of our anti-GAP-43 polyclonal antibody with GAP-43 protein abolished the immunoreactivity at the denervated endplate, making it most unlikely that the antibody recognized any other protein at the endplate. The oligonucleotide probe used in this study would also not be expected to crossreact with neurogranin $\mathrm{mRNA}$, as the predicted amino acid sequence coded by the probe does not overlap with the amino acid sequence of neurogranin (Baudier et al., 1991). The probe did recognize change in an mRNA signal in axotomized motor neurons at a time that GAP-43 expression increases in these cells (Skene and Willard, 1981) and therefore can detect changes in neural as well as Schwann cell GAP-43 mRNA levels.

A role for GAP-43 in cell shape changes has been suggested on the basis of its association with areas of substrate adhesion and actin-rich membrane (Meiri and Gordon-Weeks, 1990; Moss et al., 1990). A similar relationship has been claimed for central and peripheral glia; they express GAP -43 when they are mobile (Curtis et al., 1991). The correlation described in this study between GAP-43 expression in terminal Schwann cells and their formation of extensive branches may be related. Whether these morphological changes and GAP-43 expression are causally linked will clearly require direct manipulations, preventing transcription or translation or blocking the protein with antibodies.

Reinnervation of motor endplates by motor axons following crush injury can be monitored by axonal stains. When a silver stain is used, reinnervation is seen to begin at 8-12 $\mathrm{d}$ in the rat soleus after sciatic crush and is complete at 18-31 d (Verhaagen et al., 1988). As an alternative to silver, we have used CGRP, which is upregulated in axotomized motoneurons (Streit et al., 1989 ) and is present at a proportion of normal motor endplates (Mora et al., 1989; Reynolds and Woolf, 1992), and the neuronal marker PGP 9.5 (Wilson et al., 1988). The regrowing axons are, as expected, GAP-43 immunoreactive (see also Verhaagen et al., 1988; Hesselmans et al., 1989). At early stages of reinnervation, this means that some motor endplates contain GAP43-immunoreactive Schwann cells and some GAP-43 motor axons. It was not possible to determine if the GAP-43 immunoreactivity coexists for a short period at any given endplate, but once the normal pattern of the axonal terminal was reestablished, no Schwann cell GAP-43 staining could be detected. This raises the issue of what the signals are that switch GAP43 expression on and off in the terminal Schwann cells and in motor neurons. The switch on in the Schwann cells follows removal of the axon, and the switch off coincides with axonal reinnervation. Reinnervation of the target also results in decreased neuronal expression (Bisby, 1988), and it is conceivable that a similar signal is responsible for controlling GAP-43 in both cell types.

Since it now appears that GAP-43 is expressed in regenerating neurons and in denervated Schwann cells, it would be of considerable interest to establish if GAP-43 contributes to a particular function, related to process formation or outgrowth, that is required for different reasons by different cells at specific times during development and regeneration. It is also intriguing to speculate about the possible role of Schwann cell processes emerging from a denervated endplate in terms of the reinnervation of the endplate by regenerating motor axons. Do the processes provide a favorable substrate for axonal growth? The disorganized pattern of the processes contrasts with the highly accurate reinnervation of the endplate and makes it seem unlikely that the Schwann cell processes contribute to direct targeting of the axons onto the endplate, other cues must subserve that role. However, the Schwann cells may encourage growth to and in the general perisynaptic area so that access to more specific cues is achieved.

\section{References}

Aberdeen J, Corr L, Milner P, Lincoln J, Burnstock G (1990) Marked increases in calcitonin gene-related peptide-containing nerves in the developing rat following long-term sympathectomy with guanethidine. Neuroscience 35:175-184.

Alderson K, Pestronk A, Woon-Che Y, Drachman DB (1989) Silver cholinesterase immunocytochemistry: a new neuromuscular junction stain. Muscle Nerve 12:9-14.

Alexander KA, Cimler BM, Meier KE, Storm DR (1987) Regulation of calmodulin binding to P-57. J Biol Chem 263:7544-7549.

Baetge EE, Hammang JP (1991) Neurite outgrowth in PC12 cells deficient in GAP-43. Neuron 6:21-30.

Basi GS, Jacobson RD, Virag I, Schilling J, Skene JHP (1987) Primary structure and transcriptional regulation of GAP-43, a protein associated with nerve growth. Cell 49:785-791.

Baudier J, Deloulmer JC, Van Dorsselaer A, Brock D, Matkes HWD (1991) Purification and characterization of brain-specific protein kinase C substrate neurogranin (p17). J Biol Chem 266:229-237.

Benowitz LI, Lewis ER (1983) Increased transport of 44,000- to 49,000dalton acidic proteins during regeneration of the goldfish optic nerve: a two-dimensional gel analysis. J Neurosci 3:2153-2163.

Benowitz LI, Routtenberg A (1987) A membrane phosphoprotein associated with neural development, axonal regeneration, phospholipid metabolism and synaptic plasticity. Trends Neurosci 12:527531.

Benowitz LI, Spostolides PJ, Perrone-Bizzozero NI, Finkelstein SP, Zweirs $H$ (1988) Anatomical distribution of the growth-associated protein HAP-43/B-50 in the adult rat brain. J Neurosci 8:339-352.

Bisby MA (1988) Dependence of GAP-43 (B50,F1) transport on axonal regeneration in rat dorsal root ganglion neurons. Brain Res 458: $157-161$.

Bisby MA, Harrington KC, Tetzlaff W (1991) The growth-associated protein GAP-43 is expressed in degenerating peripheral nerve after axotomy. Soc Neurosci Abstr 17:48.

Brockes JP, Fields KL, Raff MC (1977) A surface antigenic marker for rat Schwann cells. Nature 266:364-366.

Brockes JP, Fields KL, RaffMC (1979) Studies on cultured rat Schwann cells. 1. Establishment of purified population for cultures of rat peripheral nerve. Brain Res 165:105-118.

Chandler CE, Parsons LM, Hosang M, Shooter EM (1984) A monoclonal antibody modulates the interaction of nerve growth factor with PC. 12 cells. J Biol Chem 259:6882-6889.

Chirgwin JM, Przybyla AE, Macdonald RJ, Rutter WJ (1979) Isolation of a biologically active ribonucleic acid from sources enriched in ribonuclease. Biochemistry 18:5294-5299.

Curtis R, Hardy R, Reynolds R, Spruce BA, Wilkin GP (1991) Downregulation of GAP-43 during oligodendrocyte development and lack of expression by astrocytes in vivo: implications for macroglia differentiation. Eur J Neurosci 3:876-886.

Curtis R, Stewart HJS, Hall SM, Wilkin GP, Mirsky R, Jessen KR (1992) GAP-43 is expressed by non-myelin forming Schwann cells of the peripheral nervous system. J Cell Biol 116:1455-1464.

da Cunha A, Vitkovic L (1990) Regulation of immunoreactive GAP43 expression in rat cortical macroglia is cell type specific. J Cell Biol 111:209-215.

Deloulme J-C, Janet T, Au D, Storm DR, Sensenbrenner M, Baudier J (1990) Neuromodulin (GAP-43): a neuronal protein kinase $C$ substrate is also present in $\mathrm{O}-2 \mathrm{~A}$ glial cell lineage. Characterization of neuromodulin in secondary cultures of oligodendrocytes and comparison with the neuronal antigen. J Cell Biol 111:1559-1569. 
Doster KS, Lozano AM, Aguayo AJ, Willard MA (1991) Expression of growth-associated protein GAP-43 in adult rat retinal ganglion cells following axon injury. Neuron 6:635-647.

Fidel SA, Dawes LR, Neve KA, Neve RL (1990) Effects of manipulation of GAP-43 expression on morphology of PC12 cells and cultured hippocampal neurons. Soc Neurosci Abstr 16:811.

Gorio A, Carmignoto G, Finesso M, Polato P, Nunzi MG (1983) Muscle reinnervation. II. Sprouting, synapse formation and repression. Neuroscience 8:403-415.

Hesselmans LFGM, Jennekens FGI, van den Oord CJM, Oestricher $\mathrm{AB}$, Veldman H, Gispen WH (1989) A light and electron microscopical study of B-50 (GAP-43) in human intramuscular nerve and neuromuscular junction during development. J Neurol Sci 89:301311.

Heumann R, Lindholm D, Bandtlow C, Meyer M, Radeke MJ, Misko TP, Shooter E, Thoenen H (1987) Differential regulation of mRNA encoding nerve growth factor and its receptor in rat sciatic nerve during development, degeneration and regeneration: role if macrophages. Proc Natl Acad Sci USA 84:8735-8739.

Hoffman PN (1989) Expression of GAP-43, a rapidly transported growth-associated protein and class II beta tubulin, a slowly transported cytoskeletal protein, are coordinated in regenerating neurons. J Neurosci 9:893-897.

Jessen KR, Morgan L, Brammer M, Mirsky R (1985) Galactocerebroside is expressed by non-myelin forming Schwann cells in situ. $\mathrm{J}$ Cell Biol 101:1135-1143.

Jessen KR, Mirsky R, Morgan L (1987) Myelinated but not unmyelinated axons, reversibly down-regulate N-CAM in Schwann cells. J Neurocytol 16:681-688.

Jessen KR, Morgan L, Stewart HJS, Mirsky R (1990) Three markers of adult non-myelin forming Schwann cells, 217c(Ran-1), A5E3 and GFAP: development and regulation by neuron-Schwann cell interactions. Development 109:91-103.

Kiyama H, Emson PC, Tohyama M (1990) Recent progress in the use of the technique of non-radioactive in situ hybridization histochemistry: new tools for molecular neurobiology. Neurosci Res 9:1-21.

Laemmli UK (1970) Cleavage of structural proteins during the assembly of the head of bacteriophage $T_{4}$. Nature 227:680-685.

Manolov S (1974) Initial changes in the neuromuscular synapses of denervated rat diaphragm. Brain Res 65:303-316.

Mata M, Alessi D, Fink DJ (1990) S-100 is preferentially distributed in myelin-forming Schwann cells. J Neurocytol 19:432-442.

McLean IW, Nakane PK (1974) Periodate-lysine-paraformaldehyde fixative. A new fixative for immunoelectron microscopy. J Histochem Cytochem 22:1077-1083.

Meiri KF, Gordon-Weeks PR (1990) GAP-43 in growth cones is associated with areas of membrane that are tightly bound to substrate and is a component of a membrane skeleton subcellular fraction. $\mathbf{J}$ Neurosci 10:256-266.

Meiri KF, Pfenninger KH, Willard MB (1986) Growth-associated protein, GAP-43, a polypeptide that is induced when neurons extend axons, is a component of growth cones and corresponds to pp46, a major polypeptide of a subcellular fraction enriched in growth cones. Proc Natl Acad Sci USA 83:3537-3541.

Miledi R, Slater CR (1970) On the degeneration of rat neuromuscular junctions after nerve section. J Physiol (Lond) 207:507-528.

Mirsky R, Winter J, Abney ER, Pruss RM, Gavrilovic J, Raff MC (1980) Myelin-specific proteins and glycolipids in rat Schwann cells and oligodendrocytes in culture. J Cell Biol 84:483-494.

Mora M, Marchi M, Polak JM, Gibson SJ, Cornelio F (1989) Calcitonin gene-related immunoreactivity at the human neuromuscular junction. Brain Res 492:404-407.

Moss DJ, Fernyhough P, Chapman K, Baizer L, Bray D, Allsopp T (1990) Chicken growth-associated protein GAP-43 is tightly bound to the actin-rich neuronal membrane skeleton. J Neurochem 54:729736.

Neuberger TJ, Cornbrooks CJ (1989) Transient modulation of Schwann cell antigens after peripheral nerve transection and subsequent regeneration. J Neurocytol 18:695-710.

Neve RL, Perrone-Bizzozero NI, Finkelstein SP, Zwiers H, Bird E, Kurnit DM, Benowitz LI (1987) The ncuronal growth-associatcd protein GAP-43 (B-50, F1): neuronal specificity, developmental regulation and regional distribution of the human and rat mRNAs. Mol Brain Res 2:177-183.

Represa A, Deloulme JC, Sensenbrenner M, Ben-ari Y, Bardier J (1990)
Neurogranin immunocytochemic localization of a brain-specific protein kinase C substrate. J Neurol Sci 10:3782-3792.

Reynolds ML, Woolf CJ (1992) Terminal Schwann cells elaborate extensive processes following denervation of the motor endplate. $J$ Neurocytol 21:50-66.

Reynolds ML, Fitzgerald M, Benowitz LI (1991) GAP-43 expression in developing cutaneous and muscle nerves in the rat hindlimb. Neuroscience 41:201-211.

Schotman P, Jap Tjoen San ERA, Schmidt-Michels M, Gispen WH (1990) Antisense B-50 (GAP-43) prevents neurite outgrowth in PC12 cells. Soc Neurosci Abstr 16:812.

Shea TB, Perrone-Bizzozero NI, Beermann ML, Benowitz LI (1991) Phospholipid-mediated delivery of anti-GAP-43 antibodies into neuroblastoma cells prevents neuritogenesis. J Neurosci 11:1685-1690.

Skene JHP (1989) Axonal growth-associated proteins. Annu Rev Neurosci 12:127-156.

Skene JHP (1990) GAP-43 as a 'calmodulin sponge' and some implications for calcium signalling in axon terminals. Neurosci Res [Suppl] 13:S112-S125.

Skene JHP, Virag I (1989) Post-translational membrane attachment and dynamic fatty acylation of a neuronal growth cone protein, GAP43. J Cell Biol 108:613-624.

Skene JHP, Willard M (1981) Axonally transported proteins associated with axon growth in rabbit central and peripheral nervous system. J Cell Biol 89:96-103.

Skene JHP, Jacobson RD, Snipes GJ, McGuire CB, Norden JJ, Freeman JA (1986) A protein induced during nerve growth (GAP-43) is a major component of growth-cone membranes. Science 233:783-786.

Streit WJ, Dumoulin FL, Raivich G, Kreutzberg GW (1989) Calcitonin gene-related peptide increases in rat facial motorneurons after peripheral nerve transection. Neurosci Lett 101:143-148.

Strittmatter SM, Valenzuela D, Kennedy TE, Neer EJ, Fishman MC (1990) $G_{0}$ is a major growth cone protein subject to regulation by GAP-43. Nature 344:836-841.

Taniuchi M, Clark HB, Johnson EM (1986) Induction of nerve growth factor receptor in Schwann cells after axotomy. Proc Natl Acad Sci USA 83:4094-4098

Taniuchi M, Clark HB, Schweitzer JB, Johnson EM (1988) Expression of nerve growth factor receptors by Schwann cells of axotomized peripheral nerves: ultrastructural localization, suppression by axonal contact and binding properties. J Neurosci 8:664-681.

Tetzlaff W, Zwiers H, Lederis K, Cassar L, Richardson P, Bisby MA (1989) Axonal transport and localization of B-50/GAP-43-like immunoreactivity in regenerating sciatic and facial nerves of the rat. $J$ Neurosci 9:1303-1313.

Towbin H, Staehlin T, Gordon J (1979) Electrophoretic transfer of proteins from polyacrylamide gels to nitrocellulose sheets: procedure and some applications. Proc Natl Acad Sci USA 76:4350-4354.

Traub RJ, Iadarola MJ, Ruda MA (1989) Effect of multiple dorsal rhizotomies on calcitonin gene-related peptide-like immunoreactivity in the lumbosacral dorsal spinal cord of the cat: a radioimmunoassay analysis. Peptides 10:979-983

Van der Zee CEEM, Nielander HB, Vos JP, da Silva SL, Verhaagen J, Oestreicher AB, Schrama LH, Schotman P, Gispen WH (1989) Expression of growth-associated protein B-50 (GAP-43) in dorsal root ganglia and sciatic nerve during regenerative sprouting. $J$ Neurosci 9:3505-3512.

Van Hoof COM, De Graan PNE, Oestreicher AB, Gispen WH (1988) B-50 phosphorylation and polyphosphoinositide metabolism in nerve growth cone membrane. J Neurosci 8:1789-1795.

Verhaagen J, Oestreicher AB, Edwards H, Veldman F, Jennekens GI, Gispen WH (1988) Light and electronmicroscopic study of phosphoprotein B-50 following denervation and reinnervation of the rat soleus muscle. J Neurosci 8:1759-1766.

Vitkovic L, Steisslinger HW, Aloyo VJ, Mersel M (1988) The 43-kDa neuronal growth-associated protein (GAP-43) is present in plasma membranes of rat astrocytes. Proc Natl Acad Sci USA 85:8296-8300.

Watson JB, Battenburg EF, Wong KK, Broom FE, Sutcliffe JG (1990) Substructure cDNA cloning of RC3, a rodent cortex-enriched mRNA coding a novel 78 residue protein. J Neurosci Res 26:397-408.

Wiese UH, Emson PC (1991) Intraspinal cellular responses after spinal cord transection in rats: neuronal expression of growth-associated protein (GAP-43). Res Neurol Neurosci 2:199-204.

Wilson POG, Barber PC, Hamid QA, Power BF, Dhillon AP, Rode J, Day INM, Thompson RJ, Polak JM (1988) The immunolocaliza- 
tion of protein gene product 9.5 using rabbit polyclonal and mouse monoclonal antibodies. Br J Exp Pathol 69:91-104.

Woolf CJ, Molander C, Reynolds M, Benowitz LI (1990) GAP-43 appears in the rat dorsal horn following peripheral nerve injury. Neuroscience 34:465-478.

Yankner BA, Benowitz LI, Villa-Komaroff L, Neve RL (1990) Trans- fection of PC12 cells with the human GAP-43 gene: effects on neurite outgrowth and regeneration. Mol Brain Res 7:39-44.

Zuber MX, Goodman DW, Karns LR, Fishman MC (1989) The neuronal growth-associated protein GAP-43 induces filopodia in nonneuronal cells. Science 244:1193-1195. 